\title{
Magdalena Bałaga
}

Uniwersytet Śląski

\section{Mr. Robot czyli powrót paranoi}

Erik Davis, zastanawiając się nad aktualnością jednej z powieści Williama Gibsona, stwierdza, że zarówno Hollywood, jak i najnowsza historia sprawiły, iż „antyutopijna wizja bezwzględnych informatycznych przekrętów, zbójeckich korporacji i wszędobylskich nazw firmowych stała się taką samą kliszą jak trencze i femmes fatales z czarnych kryminałów, na których wzorował się autor" (Davis, 2002, s. 244). Istotnie, od 1984 roku, w którym wydano Neuromancer (bo o tej powieści mowa), motywy te - coraz intensywniej eksploatowane stały się elementami przewidywalnymi. Co więcej, ich przedostanie się do szerszego obiegu sprawiło, że wydają się zjawiskiem o coraz mniejszym potencjale rewolucyjnym. Dlatego też każda produkcja, która poruszałaby w jakikolwiek sposób problematykę przestrzeni wirtualnej i wzrastającego znaczenia technologii w życiu człowieka, skazana jest na recykling idei i rozpoznań. Konstatacja Davisa nie jest oczywiście odkrywcza ani odosobniona, lecz przypomina o dwóch istotnych kwestiach. Po pierwsze o tym, że pewne toposy tkwią mocno w świadomości przeciętnego odbiorcy kultury. Po drugie, że te literackie/ filmowe wizje późnokapitalistycznego społeczeństwa postindustrialnego często wykorzystują elementy charakterystyczne dla historii detektywistycznych i szpiegowskich melodramatów.

Świadomość tego rodzaju ograniczeń jest obecnie czymś oczywistym. Nieobca jest również twórcom serialu Mr. Robot (2015-), którzy eksploatują te doskonale znane konwencje w ekstremalny sposób. Odniesienia do znanych tekstów kultury zostały natychmiast rozpoznane przez odbiorców, dla których ów sposób realizowania tematu stał się w takim samym stopniu wadą, jak i zaletą produkcji 
(wystarczy zajrzeć na dowolne forum traktujące o serialu). Dość wspomnieć, że to właśnie posługiwanie się znanymi schematami i kliszami sprawiło, że produkcja spotkała się z nieco ambiwalentnym przyjęciem. Część komentujących pisała nawet o „popkulturowym oszustwie” (Fisz, 2016).

Oczywiście tak radykalna teza, jakoby ta widowiskowa i świadoma intertekstualność jednocześnie osłabiała diagnostyczne aspiracje obecne w produkcji, wydaje się anachroniczna; zwłaszcza, gdy przypomnimy, że twórcy nawiązują do kanonu kultury popularnej. Dodać również należy, że liczba tych odniesień zdaje się przekraczać możliwości percepcyjne pojedynczej osoby: w zasadzie każdy z wątków nawiązuje w jakiś sposób do innego tekstu. Nic zatem dziwnego, że odbiorcy serialu śledzą owe nawiązania nie mniej uważnie od samej fabuły. Przyglądając się wypowiedziom internautów, można naliczyć kilkadziesiąt pozycji, którymi - wedle komentujących - mogli inspirować się twórcy, choć kilka z nich wydaje się wyraźniej zaakcentowanych w serialu. I tak Matrix (1999, reż. Bracia Wachowscy), American Psycho (2000, reż. Mary Harron), a nade wszystko Podziemny Krag (Fight Club, 1999, reż. David Fincher) to produkcje, które można wskazać z łatwością i które trudno zignorować. Na liście tej znajduje się również - choć nieco na dalszej pozycji - twórczość Thomasa Pynchona ${ }^{1}$.

Choć Mr. Robot nie odwołuje się do powieści amerykańskiego pisarza bezpośrednio, to wymowa tekstów amerykańskiego postmodernisty i serialu zdaje się w pewnych punktach zbieżna - przede wszystkim w zakresie wykorzystania motywu teorii spiskowych. Podejmują one z odbiorcami szczególnego rodzaju grę, która wydaje się toczyć o podobną stawkę, a mylenie tropów następuje $\mathrm{w}$ paranoicznej atmosferze. Jednakże moim zamiarem nie jest przedstawienie podobieństw i różnic pomiędzy powieściami autora $V$. i serialem. Warto natomiast podkreślić, że powieści Pynchona i $M r$. Robot posługują się niemalże tym samym kodem, reprezentują podobny sposób myślenia, wydają się stanowić efekt zbieżnych rozpoznań, a nade wszystko prowokują do zadania podobnych pytań. Co więcej, zarówno teksty amerykańskiego pisarza, jak i serial wzbudzają też podobnego rodzaju konfuzję związaną z włączaniem historii fikcyjnych w obręb wydarzeń rzeczywistych, w wyniku czego głównym zadaniem staje się ustalenie liczby związków pomiędzy nimi. Bardziej interesuje mnie zatem próba odpowiedzi na pytanie, $\mathrm{z}$ jakiego powodu tak dobrze znane z prozy Pynchona tematy na nowo odżywiają w bestsellerowym amerykańskim serialu. Choć - jak już wcześniej wspomniałam - mówi się o nim, że jest przede

Szczególnie warte zaakcentowania są pytania zadane przez użytkowników serwisu internetowego Reddit. 
wszystkim duchowym spadkobiercą Podziemnego kręgu (Szafrańska, 2015), to istotniejszy wydaje się patronat (nawet jeżeli nie zasygnalizowany wprost) najbardziej tajemniczego z amerykańskich pisarzy, będącego bodaj „najwybitniejszym kronikarzem utrwalającym te struktury myślenia i uczuciowości, które odzwierciedlają doświadczenie życia w społeczeństwie poddanym totalnemu zarządzaniu” (Sanders, 1983, s. 266).

W tak krótkim szkicu trudno oczywiście streścić którąkolwiek z powieści Pynchona. Warto jednak przypomnieć, że ich bohaterowie, między innymi Edypa Maas z 49 idzie pod mtotek, Stencil z V., Slothrop z Tęczy grawitacji czy Maxime z W sieci zaczynają ulegać przekonaniu, że rzeczywistość zorganizowana jest w tajemniczy sposób, który człowiek jest w stanie rozszyfrować, zwracając baczną uwagę na liczne, lecz niepozorne znaki. Odkrycie to trudno jednak nazwać wyzwalającym: zdemaskowanie znaczenia może być przerażające, lecz życie bez niego wydaje się równie straszne (Dickstein 1983, s. 201). Dlatego też, pomimo kilku zastrzeżeń, Pynchonowska wizja świata jest zbieżna z twórczą reakcją na doświadczenia społeczne ukazane w amerykańskim serialu. Z drugiej strony można oczywiście wskazać wiele cech powieści, które sprawiają, że Mr. Robot pod wieloma względami odbiega od niektórych tekstów autora $V$. Przykładowo, serialowi z oczywistych względów daleko do rozmachu Tęczy grawitacji i jej barokowego nadmiaru, tworzącemu połączenie groteskowego koszmaru i slapstickowej komedii (Wilczyński, 2003, s. 283). Bliżej byłoby mu raczej w tym wypadku do 49 idzie pod mtotek i W sieci, których konstrukcja imituje schemat powieści kryminalnej².

Jak już nadmieniłam, opowieść przedstawiona w serialu jest niezwykle dobrze znana; można wręcz powiedzieć, że została mocno wyeksploatowana przez kulturę. To historia młodego programisty Elliota Aldersona, który na co dzień pracuje jako specjalista do spraw bezpieczeństwa w wielkiej korporacji Allsafe. Chłopak niezbyt dobrze odnajduje się w korporacyjnej kulturze, gdyż ta, nie dość, że jest częścią silnie zhierarchizowanego środowiska, to w dodatku

2 Choć próba całkowitej rekonstrukcji „pynchonowskiej wizji świata” z pewnością przekracza ramy niniejszego artykułu, to nie sposób mówić o dziełach pisarza jako odizolowanych tekstach. Wręcz przeciwnie: nie wydaje się nadużyciem powtórzenie za Williamem M. Platerem, iż każdy kolejny utwór przynosi rozwinięcie i wzbogacenie elementów występujących we wcześniejszych dziełach (1978, s. 7). Dlatego też owa konsekwentnie budowana wizja świata sprawia, że twórczość tę należy traktować jako całościowy projekt. Komentatorzy tej prozy nie bez powodu podkreślają, że intencja pisarza jest w każdym wypadku bardzo podobna, natomiast różnice występujące w powieściach dotyczą raczej sposobu, w jaki amerykański autor prezentuje sposób rozpadu rzeczywistości (Piórko, 2011). 
wymusza na pracownikach określone modele zachowań i sposób bycia (mowa przede wszystkim o bezrefleksyjnie optymistycznej postawie). Tymczasem Eliot jest zupełnie nieprzystosowany do tak skonstruowanej rzeczywistości. Przeszkadza mu w tym przede wszystkim zespół chorób, na który cierpi, między innymi fobia społeczna, depresja i schizofrenia. Ponadto jest uzależniony od opiatów, które łączy z innymi medykamentami (nałogi te udaje mu się jednak dość szybko pokonać). Co jednak istotne, Alderson jest też niezwykle sprawnym hakerem ${ }^{3}$, a jego umiejętności są wykorzystane do sabotowania firmy, w której pracuje. Elliot zostaje zwerbowany do tajnej grupy Fsociety, której celem jest wywołanie międzynarodowej katastrofy na rynku finansowym oraz zniszczenie wszechpotężnej organizacji E-corp (AllSafe zajmuje się jej ochroną). Z czasem protagonista dowiaduje się, że wpływ tej korporacji jest dużo większy, niż można by sądzić: instytucja ma powiązania z chińskim i amerykańskim rządem. Stanowi też element międzynarodowej, tajemniczej i trudnej do zrozumienia sieci zależności.

To streszczenie fabuły nie jest oczywiście wyczerpujące, a w pewnych punktach mogłoby zostać nawet uznane za mylące. Mr. Robot jest bowiem produkcją wielowątkową i skonstruowaną w taki sposób, że wszelkie początkowe domysły odbiorcy zostają przez twórców poddane wielu próbom ${ }^{4}$. Paradoksalnie historia ta, pomimo narracyjnego chaosu odzwierciedlającego konstrukcję psychiczną bohatera, skonfrontowana zostaje z uporządkowaną przyczynowo-skutkową logiką następstw. Jednym słowem: niemal każdy, nawet najbłahszy epizod jest w serialu konsekwentnie rozwijany i rzadko kiedy pozostawiany bez odpowiedzi. Wynikiem tego jest szczególnego rodzaju konfuzja związana z przedstawianiem przez serial spójnej, choć podejrzanej historii.

Dlatego też Elliot, podobnie jak bohaterowie Pynchona, musi zmierzyć się z frustrującym i trwałym doświadczeniem każdego człowieka, jakim jest próba odnalezienia sensu w labiryncie niezrozumiałych wydarzeń. Przykładowo w debiutanckiej powieści $V$. protagonista, Herbert Stencil próbuje rozszyfrować tajemnicę nieuchwytnej, lecz wszechobecnej kobiety, której inicjał rozpoczyna się właśnie na tytułową literę. W 49 idzie pod mtotek główna bohaterka,

3 Przyjmuję nazewnictwo używane przez twórców serialu, choć można zaryzykować stwierdzenie, że bohaterów należałoby nazwać raczej crackerami. Różnica pomiędzy nimi jest taka, że haker jest osobą o wysokich umiejętnościach informatycznych, które pragnie doskonalić przede wszystkim dla własnej satysfakcji, a cracker wykorzystuje je głównie po to, by włamać się do zasobów danego komputera w celu przejęcia kontroli nad systemem. Zob. http://www.techrepublic.com/blog/itsecurity/hacker-vs-cracker/ (dostęp: 20.01.2019). Jednak potocznie częściej używa się słowa haker i zapewne stąd obecność tego słowa w serialu oraz w dyskusjach prowadzonych przez jego fanów.

4 Zastrzec przy tym należy, że dodatkowe trudności wiążą się też z faktem, że w chwili pisania tego tekstu (rok 2016) powstaje trzeci sezon serialu. W wyniku tego trudno przewidzieć sposób, w jaki potoczy się historia opowiedziana w amerykańskiej produkcji. Z konieczności ograniczam zatem swoje refleksje do treści zaprezentowanych w pierwszym i drugim sezonie produkcji. 
Edypa Maas, obarczona zadaniem realizacji testamentu swojego byłego kochanka, dowiaduje się o istnieniu tajemniczej instytucji Tristero, której znaczenia nie jest w stanie pojąć. W Tęczy grawitacji liczba wątków tworzących fabułę powieści (a jednocześnie ją zaciemniających) zdaje się przerastać percepcyjne zdolności przeciętnego czytelnika próbującego wyśledzić wszelkie informacje dotyczące enigmatycznej rakiety $V 2$. W sieci opowiada z kolei historię Maxime, kobiety prowadzącej quasi-detektywistyczną agencję tropiącą działalność nieuczciwych firm i ich związki z międzynarodowymi mafiami.

W serialu podjęto próbę podobnego wtłaczania tego typu wydarzeń w przyczynowo-skutkowy system (Wilkoszewska, 2008, s. 133), a nadawanie sensu otaczającemu światu to również stały motyw twórczości autora $V$. Problem w tym, że - jak pisał Scott Sanders - bohaterowie Pynchona skazani są na „marginalną egzystencję", oddzielającą ich od centrum rzeczywistych czy urojonych spisków, w które są uwikłani. Zmuszeni są do kojarzenia najbardziej mglistych aluzji i interpretowania najdrobniejszych zdarzeń, by tylko nadać sens biegowi zdarzeń (Sanders, 1985, s. 249). To jedna z "najbardziej charakterystycznych i chwilami denerwujących cech stylu Pynchona" - pisze krytyk (Sanders, 1985, s. 249). Stanowi ona bezpośrednią konsekwencję świadomego maskowania spisku i polega na tym, że czytelnik na każdym kroku zmuszany jest do rozpoznawania pośród pozornie neutralnych rozmów oraz autentycznych, choć ulotnych śladów zmowy. Czytelnik Pynchona doświadcza tego samego, czego bohaterowie jego książek: wie nie więcej niż oni sami, a przecież trudno nie dostrzec, że wiedza ta bywa niewystarczająca; narrator zaś, jeżeli nawet wie coś więcej, rzadko to ujawnia.

Nie inaczej jest w przypadku amerykańskiego serialu. Historia opowiadana przez Elliota nieustannie podawana jest w wątpliwość. Dzieje się to przede wszystkim za sprawą stosowania szczególnej odmiany narracji voice over. W roli zwodniczego narratora występuje oczywiście Elliot, który większość swoich monologów rozpoczyna od charakterystycznego „hello, friend”, zwracając się tym samym bezpośrednio do widza. Co więcej, skrajnie subiektywna narracja Elliota zdaje się historią konstruowaną w czasie teraźniejszym. Ta konstrukcja jest jednak niezwykle niestabilna, a sytuacje przedstawiane na ekranie i komentowane przez narratora z czasem coraz trudniej utożsamić z rzeczywistym przebiegiem zdarzeń. Dzieje się tak dlatego, że dowiadujemy się o chorobach psychicznych Elliota (głownie dysocjacyjnych zaburzeniach tożsamości i schizofrenii). To oczywiście może wyjaśniać przyczynę narracyjnego chaosu doświadczanego przez widza. Informatyk ma urojenia i sam nie potrafi oddzielić fałszywych przekonań od obiektywnych zdarzeń. Bezustannie komentuje wydarzenia, zastanawia się nad wieloma kwestiami i powątpiewa w większość 
zdarzeń, których jest uczestnikiem. Wszystko to sprawia, że opowieść ta zdaje się „spontaniczną, bezpośrednią transmisją z jego świadomości, a nie tylko narracyjnym narzędziem w rękach scenarzystów” (Kućmierz, 2015).

Uczynienie bohaterem serialu $M r$. Robot korporacyjnego informatyka jest uprawomocnione z kilku powodów. Serial stanowi po części twórczą reakcję na nowe doświadczenia społeczne, a zatem trudno o bardziej typowego współczesnego bohatera aniżeli szeregowy pracownik korporacji. Po drugie, postać Elliota kumuluje w sobie większość obaw współczesnej jednostki. Jego choroba wydaje się bowiem nie tyle sposobem na przedstawienie case study konkretnej dysfunkcji, co próbą zobrazowania problemów, z jakimi borykają się jednostki niedostosowane do życia w turbokapitalizmie. A zatem fobia społeczna Elliota stanowi tak naprawdę hiperboliczną reprezentację lęków przed oceniającym społeczeństwem. Schizofreniczne rozmowy ze zmarłym ojcem mogą wynikać zarówno z potrzeby bliskości, jak i niemożności pogodzenia się z utratą przedwcześnie utraconego dzieciństwa. Z kolei depresja to obraz uczuć jednostki odrzucającej bezrefleksyjny hiperoptymizm i przez to traktowanej jako niedostosowana do wzorów osobowościowych lansowanych przez media społecznościowe i korporacje. Oczywiście przypadłości Elliota - jak już wspomniałam - jest również pretekstem do podjęcia eksperymentów na gruncie serialowej narracji. Historia jego choroby to świadectwo indywidualnego szaleństwa, ale i problemów, z jakimi boryka się znaczna część społeczeństwa.

Temu narracyjnemu chaosowi przeciwstawione zostają kompozycje kadru o niezwykle ascetycznym charakterze. Ich kolorystyka ograniczona jest do bieli, czarni, szarości, imitując w ten sposób charakterystyczną architekturę wielkich korporacji. Większość przedstawia właśnie takie minimalistyczne, oszczędne wnętrza, w których dominuje stal i szkło. Czasem pojawiają się oczywiście bardziej dynamiczne i kolorowe obrazy miasta, jakby nieco w kontrze do zamkniętych korporacyjnych pomieszczeń (najpewniej są to obrazy Nowego Jorku, choć w żadnym $\mathrm{z}$ odcinków nazwa ta nie pada wprost). Większość kadrów została skonstruowana w oparciu o zasadę trójek (Van der Verff, 2015; Tomaszewski, 2016), co dodatkowo potęguje poczucie niepokojącego porządku. Zabieg ten wykorzystany zostaje w charakterystyczny i precyzyjny sposób: oto kluczowym elementem kompozycji staje się zazwyczaj pusta przestrzeń, a postacie umieszcza się zazwyczaj „na skraju” kadru. Podkreśla to alienację bohaterów i ich zagubienie, jednocześnie akcentując pozory porządku gwarantowanego przez korporacyjny system czy społeczne relacje. Paradoksalnie ta niezagospodarowana przestrzeń 
nie daje poczucia wolności, lecz sprawia wrażenie przebywania w klaustrofobicznej pułapce. W takim kontekście najczęściej wykorzystywane są pomieszczenia E-corp - miejsca pracy introwertycznego informatyka (które w jego świadomości istnieje pod nazwą Evil Corp).

Motyw wszechwładnej korporacji nie pojawia się oczywiście przypadkowo i pełni podwójną rolę. Po pierwsze, trudno wskazać instytucję, która obecnie tak mocno kształtowałaby sposób myślenia współczesnego człowieka: panujące w niej zasady, hierarchia i uniformizacja wywarły niebagatelny wpływ na postrzeganie świata. Elliotowi to miejsce również kojarzy się wyłącznie negatywnie: otoczony kolegami, którzy poddają się rygorom narzuconym przez firmę, czuje się niezrozumiany i nieszczęśliwy. Po drugie - i to ujęcie wydaje się bliższe Pynchonowskiej wizji świata - serial przedstawia korporację jako symbol wszechwładzy; instytucję w tajemniczy sposób powiązaną z najważniejszymi politycznymi organizacjami, których działania nie są zrozumiałe dla przeciętnego człowieka.

Trudno jednak jednoznacznie stwierdzić, na czym ów spisek miałby polegać. Powtórzę zatem - choć z początku wydaje się, że Elliot występuje przeciwko dobrze znanym zagrożeniom współczesnego świata (wyartykułowanym i zinterpretowanym wcześniej w znanych już tekstach kultury), takim jak uniformizacja, dehumanizacja czy kontrolowanie społeczeństwa - bohater dość szybko staje się trybikiem bardziej skomplikowanego systemu powiązań. Początkiem tej drogi jest moment hakerskiego ataku na AllSafe i odczytanie przez protagonistę zaszyfrowanej w systemie informacji. Od wpisania rodzaju komendy (brzmiącej po prostu tak lub nie) zależeć będzie, czy stanie się on członkiem hakerskiej organizacji.

Wspomniana sytuacja, porównywalna do sceny znanej z Matrixa, innego intertekstu dla serialu, nie powinna zostać zlekceważona. Główny bohater filmu Wachowskich, Thomas, też musiał wszak zadecydować, czy wybierze czerwoną, czy niebieską pigułkę. Jest to jednak gest nieświadomego człowieka, umożliwiający odrzucenie fałszywego systemu pojęć i tym samym uzyskanie wiedzy. Bohater Matrixa kształtuje swoją wiedzę, by nabyć określoną tożsamość, porzucając przy okazji poprzednią, i stwierdzić z przekonaniem: „nazywam się Neo”. W przypadku Elliota sprawa jest nieco bardziej skomplikowana, bowiem wybór nie sprowadza się do pytania: „czy wybierasz szczęśliwe życie w nieświadomości, czy wolisz uzyskać przerażające, lecz wyzwalające informacje?”. Alderson zdecydował o tym już dużo wcześniej: nie ma wątpliwości co do kierunku, w jakim chce podążać, a wprowadzenie komendy, która potwierdzi jego przyłączenie do hakerskiej grupy, należy traktować jako potwierdzenie jego wcześniejszych po- 
dejrzeń i refleksji5. Decyzja wiąże się raczej ze sposobem, w jaki tę wiedzę wykorzysta; innymi słowy, czy jego lokalne działania będą podejmowane na większą skalę.

Wkroczenie na „poziom globalny” pociąga ze sobą szczególne konsekwencje. Przede wszystkim Elliot musi poradzić sobie z narastającym wokół niego chaosem. A przecież, jak wcześniej zasygnalizowałam, ów informacyjny zamęt jest podwójny - wiąże się bowiem z próbami zapanowania zarówno nad swoją chorobą i uzależnieniami, jak i nad ciągle napływającymi nowymi danymi uzyskuje uzyskanymi na skutek przystąpienia do organizacji Fsociety. Z czasem bohater nabiera przekonania, że świat jest podporządkowany spiskowi tworzonemu przez rządy państw i międzynarodowe korporacje, a także podziemne organizacje. Musi zatem poradzić sobie nie tylko z chorobą zaburzającą jego sposób postrzegania świata, ale również ze sprzecznymi sygnałami, które otrzymuje ze świata zewnętrznego. W jednym z odcinków pojawia się też informacja, że mężczyzna doświadczył amnezji wstecznej, w wyniku czego nie pamięta znacznego fragmentu swojego życia. Zdarzenia z przeszłości reprezentowane są zresztą w zupełnie inny sposób, czego przykładem jest nierozpoznawanie rodziny. W innym z odcinków Elliot jest autorem głównego, destrukcyjnego planu hakerskiej grupy Fsociety (niestety, nie ma on pojęcia w jakim celu go stworzył i w jaki sposób mają przebiegać działania umożliwiające jego wykonanie). Obie kwestie (choroba i poczucie zagrożenia związane z odkryciem spiskujących organizacji) trudno jest od siebie odseparować: zaburzają nie tylko sposób narracji, ale również nie pozwalają odbiorcy na uzyskanie jasnej informacji na temat wiodącego wątku serialu. Trudno bowiem wskazać, co jest li tylko wytworem wyobraźni Elliota, a co wynikiem działań osób zamieszanych w międzynarodową intrygę.

Elliot doświadcza zatem tego, co stało się również udziałem Pynchonowskich bohaterów: paranoicznego przekonania o istnieniu alternatywnej rzeczywistości, której odkrycie nie jest ani łatwe, ani trudne. Aby ją poznać, należy poprawnie odczytywać sygnały z zewnątrz, nie ignorując swojej intuicji. Jednakże w obu przypadkach mowa o uwięzieniu między dwoma światami: konwencjonalnym

\footnotetext{
5 W przeciwieństwie do możliwości, którą otrzymuje Neo w Matrixie, wybór Elliota nie jest zerojedynkowy (pozostać czy „wylogować się” z wirtualnego świata). Twórcy Matrixa sugerują bowiem, że osiągalny jest całkowity powrót do nieświadomości, to znaczy taki, o jakim marzył jeden z bohaterów filmu, Cypher. Jest to postać rozczarowana wyborem czerwonej pigułki (a tym samym odkryciem, w jaki sposób naprawdę funkcjonuje świat). Wybór w Matrixie zdaje się ograniczać do tego, czy jednostka sama stworzy swoje życie, czy też żyje w sposób, który wybrano dla niej (czego najbardziej skrajną formą jest sytuacja absolutnej nieświadomości w przypadku ludzi podłączonych do elektrowni jako paliwo przeznaczane do podtrzymania funkcjonowania sztucznej inteligencji). Elliota może jedynie przejmować coraz więcej danych, których nigdy nie zapomni, przetwarzać je i w różny sposób interpretować, zastanawiając się, co jest prawdą, a co wytworem wyobraźni (choroby); tym samym nigdy nie „oczyści” swojego umysłu.
} 
i paranoicznym, przy czym w obu szaleństwo objawia się na swój sposób. Powróćmy zatem do tego najbardziej frapującego elementu $\mathrm{Mr}$. Robot, jakim jest nadanie przeżyciom paranoidalnej jednostki, żyjącej w turbokapitlistycznej rzeczywistości, uniwersalnego wymiaru kondycji ludzkiej.

„Paranoja” to termin, który pojawia się zawsze, ilekroć mowa o twórczości Pynchona. Samo pojęcie ma oczywiście medyczny rodowód; w tradycji amerykańskiej psychiatrii oznacza nie tyle konkretną chorobę, lecz zespół zjawisk psychopatologicznych obejmujących przede wszystkim „podejrzliwość i poczucie zagrożenia osiągające wymiar urojeń oraz działania mające na celu uchronienie się przed urojonym niebezpieczeństwem" (Kuhn, 1996, s. 5) i pojawiający się w wielu zaburzeniach psychicznych, począwszy od schizofrenii, na uzależnieniach od substancji psychoaktywnych skończywszy. „Pynchonowską odmianę paranoi” bodaj najtrafniej podsumował Morris Dickstein:

[n]ie jest ani stanem klinicznym, ani też literacką „spiskową” wizją historii, lecz metaforą czegoś, co łączy powieściopisarza z mistykiem, narkomanem, filozofem i naukowcem. Jest to szaleńcze łaknienie znaczenia, fascynujące i niepokojące zarazem przypuszczenie, że rzeczy nie są tym, czym wydają się na pozór, że cała rzeczywistość zorganizowana jest w tajemniczy sposób i że zdołamy ją rozszy frować, zwracając baczną uwagę na setki niepozornych znaków i sugestii. Jest to wreszcie przypuszczenie, iż bez ukrytego porządku lub znaczenia życie jest suche i jałowe, lecz może być przerażające, kiedy znaczenie to zostanie odkryte (Dickstein, 1983, s. 201).

Charakterystyczna dla Pynchona „paranoidalna wizja świata” to - jak pisze Lech Budrecki - efekt pewnej właściwości ludzkiego umysłu, który broni się przed chaosem, a nade wszystko pragnie takiego obrazu rzeczywistości, który nie byłby zbiorem niepowiązanych ze sobą faktów (Budrecki, 1983, s. 229). Jednak to, co odróżnia Elliota od większości paranoicznych bohaterów to fakt, że ci drudzy zaczynają wątpić w swoją poczytalność dopiero z czasem, to znaczy w miarę przyswajania nowych, wzbudzających coraz większą podejrzliwość informacji. W przypadku Elliota jest nieco inaczej: wzmianka o jego psychicznych dysfunkcjach pojawia się niemal natychmiast w pierwszym odcinku. Jest to zatem główny powód, dla którego Elliot - jako narrator historii - jawi się nam jako osoba niewiarygodna. Taki stan rzeczy ma konkretne przełożenie na recepcję opowiadanej historii, bowiem trudność sprawia oddzielenie fantazji bohatera od obiektywnie dziejących się zdarzeń. Co więcej, protagonista nawet nie rości sobie praw do obiektywności. Dość przypomnieć, że w drugim sezonie aż siedem odcinków prezentuje prowadzoną przez Elliota opowieść o tym, 
co działo się z nim i hakerską grupą po zrealizowaniu planów zniszczenia systemu bankowego. Chłopak drobiazgowo relacjonuje przebieg wydarzeń po katastrofie, jaką sprowadził atak Fscociety. Opowiada też między innymi o swoim pobycie w domu matki, uczęszczaniu na spotkania terapeutyczne pomagające zmierzyć się z chorobą, świadomym odcięciu się od grupy hakerskiej i jednocześnie wplątaniu w zupełnie inną aferę związaną z tak zwanym darknetem, czyli siecią przeznaczoną jedynie dla osób wtajemniczonych i kontrolowaną przez przestępcze organizacje; przestrzenią, w której handluje się nielegalnymi substancjami, bronią czy dziecięcą pornografią. Wszystko jednak okazuje się wytworem wyobraźni Elliota, stworzonym podczas pobytu w więzieniu. Okazuje się, że odsiaduje on krótki wyrok za błahe przestępstwo, jakim jest kradzież psa, nad którym znęcał się poprzedni właściciel, oraz za włamanie się na konto internetowe oprawcy zwierzęcia.

Ten zwodniczy tryb opowiadani jest charakterystyczny również dla Pynchona. Przykładowo: w Tęczy grawitacji pojawia się fikcyjny narrator, w szczególny sposób prowadzący narrację. Zwraca na niego uwagę Lech Budrecki: „Jest on postacią określoną dość wyraźnie, choć pisarz nie nadaje mu ani imienia, ani nazwiska. Naznacza go wszakże swego rodzaju piętnem osobowym. Nie sprowadza się ono do tych czy innych upodobań leksykalnych czy syntaktycznych" (Budrecki, 1983, s. 235). Na ostatnich stronach Tęczy grawitacji fikcyjny narrator zdaje się sugerować, że do tej pory przekazywał tylko fabułę filmu. Podobnie jest też w przypadku Edypy zadającej sobie pytanie o to, czy „wymyśla sobie właśnie świat”, zastanawiając się nad solipsystycznym charakterem swoich działań.

„To już nie pytanie, co widzę. Bo to niewiarygodne źródło. Właściwe pytanie brzmi: czego nie widzę?” - zastanawia się Alderson i tak wyrażoną wątpliwością przekreśla jakąkolwiek wiarygodność swoich działań. To położenie niezwykle dramatyczne, tragiczniejsze nawet od tego, które stało się udziałem Thomasa Andersona z Matrixa. O ile bowiem z czasem zaufa przewodnikom wprowadzającym go w zasady świata, o którym nie miał pojęcia, o tyle Elliot nie potrafi odróżnić fikcji od rzeczywistości, wytworów swojej fantazji od prawdziwych wydarzeń, a potencjalny przewodnik ma objawy zaburzeń osobowości.

„Hakerzy mają powiedzenie: kto raz zszedł głęboko, nigdy więcej nie zaśnie” - stwierdza jedna z bohaterek powieści W sieci, Vyrva (Pynchon, 2013, s. 90). Oczywiście powiedzenie to sugeruje, że raz uzyskane i zinterpretowane informacje nie pozwalają na zignorowanie pozyskanej wiedzy. Jednak zacytowane słowa 
mają również bardziej dosłowny charakter i mogą stać się pretekstem do rozważań na temat zagadnień przedstawionych w omawianym serialu.

Rzecz bowiem w tym, że $M r$. Robot przedstawia hakerów jako grupę o swoistej nadświadomości. Serialowy zespół Fsociety to odpowiednik istniejącej realnie grupy aktywistów sprzeciwiających się ograniczaniu wolności obywatelskich, konsumpcjonizmowi, korupcji i korporacjonizmowi. Anonymous - bo o nich mowa - jest jednak globalna i silnie zdecentralizowana, w przeciwieństwie do kameralnego Fsociety, do którego należą tylko najbardziej zaufani. Łączą ich podobne poglądy na rzeczywistość i antykapitalistyczne nastawienie. Trudno jednak stwierdzić, co chcą osiągnąć: z pewnością ich celem jest wprowadzenie chaosu i zaburzenie korporacyjno-bankowego systemu generującego nierówności. Działania tej anonimowej grupy skonfrontowane są z inną tajemniczą organizacją Dark Army, o wiele bardziej enigmatyczną i niebezpieczną. O ile członkowie Fsociety przypominają anarchistycznych reakcjonistów, o tyle Dark Army stanowi coś na kształt bezwzględnej, międzynarodowej i nieobliczalnej mafii.

Zarówno zacytowana powieść $W$ sieci, jak i $M r$. Robot traktują w gruncie rzeczy o tym samym: o możliwościach, jakie zapewnia obecnie internet - nie stanowiący wcale jednolitego systemu. W obu tekstach poruszone zostaje zagadnienie technologii istniejącej poza granicami bezpieczeństwa. Pynchon mówi o bleeding edge, czyli głęboko ukrytej sieci. W serialu (nieco pokrętnie) wspomina się za to o przestrzeni darknetu, czyli ukrytej dla przeciętnego użytkownika wirtualnej przestrzeni. Mówiąc o tym obszarze sieci, często wykorzystuje się metaforę góry lodowej. Popularne wyszukiwarki, portale społecznościowe czy serwisy informacyjne stanowią tylko wierzchołek. Darknet jest wszystkim tym, co niewidzialne, ciemne i mroczne; przestrzenią, pozbawioną zasad, służącą zarówno do wymiany tajnych informacji, jak i handlowania zakazanymi przedmiotami. Problem internetowej komunikacji zostaje zatem poszerzony o kolejny aspekt. Mając do dyspozycji tę wiedzę, można uznać, że internet stanowi nie tylko głęboki ocean, z którego trudno jest wyłowić informacje ze względu na ich ilość. Problemem jest raczej istnienie kolejnych, niekoniecznie kontrolowanych, poziomów. Anonimowość, tak charakterystyczna dla przestrzeni internetu i wynikająca z zabezpieczeń i bezsilność jednostek rządowych i służb specjalnych, za sprawą darknetu staje się ekstremalna, a zaszyfrowane dane - zawierające niedostępne powszechnie informacje - są jedną z najmroczniejszych tajemnic współczesnego świata.

Nie ma większego znaczenia, czy serial i książka przedstawiają rzeczywiście istniejący darknet, czy tylko przetwarzają fantazje z nim związane. Kluczowe wydaje się to, że rozszyfrowanie kolejnych poziomów internetu jest równoznaczne z odkrywaniem coraz to nowych obszarów, w których fikcja miesza się z rzeczy- 
wistością. Co więcej, właśnie Internet dostępny każdemu obywatelowi jawi się jako ten najbardziej niebezpieczny - w końcu stanowi najpotężniejsze narzędzie inwigilacji jednostek, nieświadomie udostępniających informacje na swój temat (protagonista potrafi wykorzystać to do dobrych celów, na przykład tropiąc i karząc pedofila).

Choć o internetowym chaosie traktuje przede wszystkim wspomniana książka $W$ sieci, wydaje się, że problematykę tę oddaje najpełniej wcześniejsza powieść 49 idzie pod mtotek. Można zaryzykować stwierdzenie, że organizacja Tristero, poszukiwana przez bohaterkę powieści, Edypę Maas, stanowi swoistą antycypację. Przeczucie, że istnieje zupełnie inna sieć komunikacji - w opozycji do tej oficjalnie używanej - to wszak główny temat powieści. W 49... działa również tajna organizacja zacierająca swoje ślady. Co więcej, historia Tristero splata się z działalnością organizacji pocztowej służącej komunikowaniu się w sposób nieinstytucjonalny i stworzonej przez ludzi, z różnych przyczyn pragnących odciąć się od obowiązujących reguł postępowania (Cieński, 1985, s. 196). Zarówno Elliot, jak i Edypa próbują zatem odnaleźć coś owianego tajemnicą, nieznanego, a będącego dowodem na jej istnienie. Marcin Cieński trafnie zauważa, iż „Pynchon pokazuje, że opisane przez niego mechanizmy działania społeczeństwa nie są wynalazkiem ostatnich lat, wynikiem działania samochodu, maszyny cyfrowej czy narkotyków. Zawsze istniało bowiem to, co ukryte pod powierzchnią oficjalnego systemu wartości, wywierało wpływ na ludzkie zachowania, budziło lęk i grozę (Cieński, 1985, s. 2015).

Powieść i serial, pomimo odległości czasowej dzielącej oba dzieła, traktują o podobnej kwestii. Tym, co łączy Elliota i Edypę, jest oczywiście nieumiejętność odczytywania znaków i popadanie w coraz większą obsesję spowodowaną uczuciem bycia podporządkowanym bezosobowym siłom. W 49 idzie pod mtotek pojawiają się takie oto słowa:

Być może naprawdę [...] trafiłaś na sieć, przy pomocy której naprawdę porozumiewają się Amerykanie, pozostawiając oficjalnej poczcie rutynowe frazy, kłamstwa i oznaki umysłowego ubóstwa; może natrafiłaś na prawdziwą alternatywę ślepego zaułka pozbawionego niespodzianek życia, którego wizja prześladuje wszystkich Amerykanów, ciebie także kotku. Lecz być może masz po prostu halucynacje. Lub też zadzierzgnięto wokół ciebie spisek, kosztowny i dopracowany (...), spisek tak zawikłany, że musiał być czymś więcej niż zwykłym żartem. Albo też spisek jest dziełem twej wyobraźni, a w takim przypadku jesteś chora, Edypo, i masz nierówno pod sufitem (Pynchon, 1987, s. 180). 
Morris Dickstein pisze, że Pynchon postanowił „uromantycznić Edypę i uczynić z niej buntowniczkę" (1983, s. 202). „W ostatniej scenie - pisze krytyk - Edypa z «odwagą, jaką odkrywamy w sobie, gdy nie ma już nic do stracenia», przygotowuje się do ostatecznego posunięcia, które ma wyjawić tajemnicę Tristero. Nie jest jednak postacią heroiczną (...), lecz jedynie - skromnym ośrodkiem wartości w świecie, gdzie wartości ludzkie zostały zniekształcone lub zapomniane" (Dickstein, 1983, s. 202). Podobnie rzecz ma się z Elliotem - heroizm tego skrajnie introwertycznego informatyka jest jednak jeszcze słabiej dostrzegalny.

49 idzie pod mtotek i Mr. Robot dają się odczytać jako opowieść o doświadczeniach społecznych, które wydają się w takim samym stopniu elementem bezkształtnej rzeczywistości, jak wynikiem międzyludzkich relacji, lęków i obsesji. W gruncie rzeczy system Tristero, korporacyjne intrygi i tajemnicze sieci powiązań poruszają o wiele mniej, aniżeli rytm zaniepokojonego umysłu wystawionego na wszystkie wspomniane próby. W gruncie rzeczy stanowią one równoznaczne elementy, podporządkowujące teksty szczególnej dominancie ontologicznej, rozwijając pytania dotyczące ontologii samego tekstu bądź też ontologii projektowanego przezeń świata. Dick Higgins nazywa takie pytania "postpoznawczymi” (McHale, 1996, s. 351). Można by je sprowadzić do refleksji na temat ustrukturyzowania i zaprojektowania świata. W swoim szkicu Brian McHale wymienia takie przykładowe pytania (nie jest to oczywiście zamknięty katalog): „Z jakim światami mamy do czynienia? Jak są one zbudowane i czym się między sobą różnią? Co się dzieje, gdy dochodzi do konfrontacji między tymi światami lub gdy granice między nimi ulegną przerwaniu?” (McHale, 1996, s. 351). W Mr. Robot funkcjonują one w wersji popularnej - głównie po to, by podjąć refleksję nad problemem anonimowości, a tym samym samotności jednostki funkcjonującej w korporacyjnym i technologicznie zdominowanym świecie.

Zarówno Pynchonowski obraz świata, jak i ten wyłaniający się z serialu stanowią jednakże twórczą reakcję na doświadczenia społeczne, z paranoją jako psychologicznym odpowiednikiem sposobów społecznej organizacji. Jak zauważył Douglas Hofstadter, paranoidalne sposoby myślenia nasilają się zwykle w czasach "konfliktów społecznych, angażujących skrajnie odmienne systemy wartości” (Hofstadter, za: Sanders, 1985, s. 265) - dla Pynchona najlepszym przykładem takiej sytuacji była wojna wraz z jej złowieszczymi wynalazkami technicznymi. Jednak W Sieci problematyka ta $\mathrm{z}$ wiadomych względów ustępuje władzy elektronicznym urządzeniom do inwigilacji - tak jak w Mr. Robot. Nie jest zatem przypadkiem, że bohater zmuszony zmierzyć się z potężnymi instytucjami będącymi tajemnicą dla funkcjonariuszy wszystkich szczebli i egzystujący w paranoidalnej urzeczywistnionej fantazji wydaje się najlepszym symbolem obywatela. To właśnie 
cechy współczesnego systemu ekonomicznego (z rządzącymi korporacjami), politycznego (turbokapitalizm z metodami organizacji służącymi realizacji coraz bardziej nieracjonalnych celów) oraz nieustanne egzystowanie w przestrzeni internetu, którego znaczenie wciąż rośnie, sprawiają, że powrót paranoi w tekście o nowych doświadczeniach społecznych jest nieunikniony.

\section{Bibliografia}

Budrecki, L. (1983). Piętnaście szkiców o nowej prozie amerykańskiej. Warszawa: Czytelnik.

Cieński, M. (1985). Rytuaty Thomasa Pynchona. „Literatura na świecie”, nr 7.

Davis, E. (2002). TechGnoza. Mit, magia i mistycyzm w wieku informacji (tłum. J. Kierul). Poznań: Rebis.

Dickstein, M. (1983). Czarny humor a historia (tłum. J. Anders), [w:] Z. Lewicki (red.), Nowa proza amerykańska. Szkice krytyczne. Warszawa: Czytelnik.

Fisz, W. (2016) Mr. Robot: popkulturowe oszustwo i przereklamowany serial. http:// naekranie.pl/artykuly/mr-robot-popkulturowe-oszustwo-i-przereklamowany-serial (dostęp: 22.07.2016).

McHale, B. (1996) Od powieści modernistycznej do postmodernistycznej: zmiana dominanty (ttum. M.P. Markowski), [w]: R. Nycz (red.) Postmodernizm. Antologia przektadów. Kraków: Wydawnictwo Baran i Suszczyński.

Kućmierz, K. (2015). Widz nie istnieje. O serialu Mr. Robot. „Kultura liberalna”, nr 42.

Piórko, L. (2011). Wariacje postmodernistyczne w prozie Thomasa Pynchona. „Acta Universitatis Wratislaviensis", nr 3323.

Plater, W. (1978). The Grim Phoenix: Reconstructing Thomas Pynchon. Indiana University Press.

Pynchon, T. (1987). 49 idzie pod mtotek (tłum. P. Siemion). „Literatura na świecie”, nr 7. Pynchon, T. (2013). W sieci (tłum. T. Wyżyński). Warszawa: Albatros.

Siegel, R. K (1996). Szepty. Rzecz o paranoi (tłum. K. Kuhn). Warszawa: WAB.

Szafrańska, K. (2015). Mr. Robot: Dziesięć rzeczy, które warto wiedzieć o serialu. http:// www.youtube.com/watch?v=qCsP7c4swMc (dostęp: 13.04.2016).

Tomaszewski, M. (2016). Who is Mr. Robot? http://lekturaobowiazkowa.pl/na-ekranie/ who-is-mr-robot/ (dostęp: 13.04.2016).

Van der Verff, T. (2016). USA's Mr. Robot Became an Obsession Thanks to This One Weird a Visual Trick. http://www.vox.com/2015/8/26/9211751/mr-robot-direction-best (dostęp: 13.04.2016).

Wilczyński, M. (2003). Proza eksperymentalna lat 60. i 70., [w]: A. Skalska (red.), Historia literatury amerykańskiej XX wieku. Tom 2. Kraków: Towarzystwo Autorów i Wydawców Prac Naukowych „Universitas”.

Wilkoszewska, K. (2008). Wariacje na postmodernizm, Kraków: Towarzystwo Autorów i Wydawców Prac Naukowych „Universitas”. 


\section{Mr. Robot: The Return of Paranoia}

The aim of this paper is to show the functioning and the role of paranoid obsessions in television series Mr. Robot (2015-) and Thomas Pynchon's novels. Although it seems that the novels of the American writer and the screenplay have little in common, both use a paranoid way of thinking as a creative response to societal experience.

Słowa kluczowe: $M r$. Robot, serial telewizyjny, eksperyment społeczny

Keywords: Mr. Robot, television series, societal experience 